\title{
The Partnership Model for The Diploma of Fashion Designer and The Fashion Industry
}

\author{
Ratna Suhartini ${ }^{1, *}$ Ekohariadi ${ }^{2,3}$, Urip Wahyuningsih ${ }^{1}$, Yulistiana ${ }^{1}$, Yuhri Inang \\ Prihatina $^{1}$, Muchlas Samani ${ }^{4}$ \\ ${ }^{1}$ Fashion Design Vocational Program, Universitas Negeri Surabaya, Surabaya, Indonesia \\ ${ }^{2}$ Department of Informatics Engineering, Universitas Negeri Surabaya, Surabaya, Indonesia \\ ${ }^{3}$ Postgraduate Study Program, Universitas Negeri Surabaya, Surabaya, Indonesia \\ ${ }^{4}$ Mechanical Engineering Department, Universitas Negeri Surabaya, Surabaya, Indonesia \\ *Corresponding author. Email: ratnasuhartini@unesa.ac.id
}

\begin{abstract}
This study aims to describe the partnership model for the diploma of fashion design and fashion industry, which has already been implemented, and describe the partnership model needed. Data is collected by interview, observation, and documentation. The results show that the partnership between the diploma of fashion design and the fashion industry is mutually beneficial in terms of providing labor for the fashion industry and real work practices for the fashion design diploma. The partnership model that is needed is persuading the practice of fashion design and clothing production carried out in the industry, with the lecture model carried out in the one-month study program and the one-month industry, learning outcomes are assessed by the industry. Internships for lecturers are held every year for one month. Fieldwork practices include design, clothing production, pattern maker, and business management. Student selfdevelopment ahead of graduation, following fashion activities in the fashion community.
\end{abstract}

Keywords: Fashion Design Diploma, Fashion Industry, Models, Partnership

\section{INTRODUCTION}

Diploma programs in fashion design are one of the environmental studies programs at the State University of Surabaya. Referring to law number 12 the year 2012 goal of fashion design diploma is producing graduates expected to have attitudes and values competencies, knowledge, skills and general skills Special. To achieve these objectives an alternative strategy is done in the development of learning, human resource development, development of quality partnerships. Learning developed based on competencies that are relevant to the industry. To improve the relevance of learning materials with industry, the activities of the tracer study were conducted at regular intervals, where the input of external stakeholders (users, alumni, Government, private associations, and profession) is a change in the curriculum materials. The results of the tracer material lecture about the relevance of $70 \%$ are very appropriate, $20 \%, 10 \%$ is not appropriate. This shows that there is still the lecture material that has not been appropriate, namely the practice of making design and making clothing following the trend and following the fashion industry.

Learning is conducted in the form of lectures, practical work, seminars, and a final assignment with the indicators of achievement following that stated in the Learning Plan the semester. $90 \%$ done lectures in the classroom and the lab's field of study and $10 \%$ is done in the industry (2016 accreditation Form). Theory and practice of learning results assessed by professors, using appropriate indicators prepared criteria. The assessment has not been referring to the standard of the industry. Assessment of the limited results of practice, not to touch the eligibility of products according to the consumer. Learning in the industry include the real product according to the product produced by the industrial, industrial atmosphere, communicating with employees, customers, and management. Learning is not retrieved if the learning is done in the classroom and lab courses. 
The practice in the fashion study program uses a lot of the main ingredients, namely fabrics, additives, namely lining, fusible interfacing, complementary materials such as buttons. The use of these materials is adjusted to the type of practice. The suitability of the material of practice material will determine the product produced. These demands require large fees. The average student is an intermediate economy, so it is difficult to meet these demands so that the prescribed practice materials do not meet the criteria. The results of practice products are not optimal. Learning practices in the industry are profitable. Material can be obtained from the industry according to the order. Up to date design and sewing techniques according to the material, and practically efficient. Students do not pay practice fees.

Opportunities for students to develop themselves are met with an understanding of the special materials special courses of choice as many as 2 credits. Students choose suits their abilities, determine the topic thesis is given full opportunity to choose topics that are becoming the choice of appropriate design clothing that's been laid out and presented, students are capable of independent study in order developing his skills. This is apparent in the way of completing the case studies given at the time the lectures are tailored to each situation, in implementation learning students are given tasks that are performed independently as making fashion products deliver presentations and seminars on related topics that have been studied. The implementation of the practice of fieldwork in the fashion industry to national standards.

They improve the ability of lecturers gradually by attending workshops on the preparation of semester learning plans, teaching materials, Applied Approach training held by universities, and training in fashion training. Fashion always changes according to trends. Not all changes can be followed by lecturers as teaching staff, due to time, cost, and information limitations. Based on the above problems, a link between the fashion design diploma and the fashion industry is needed, in the form of partnerships

\section{LITERATURE REVIEW}

\subsection{Public-Private Partnership}

The understanding of Public-Private Partnership according to the World Bank (2014: 25) says that "Governments looking at options to improve performance of existing public assets and services in these sectors may consider a PPP as an alternative sector reform option to privatizing and establishing a regulatory regime" [1]. Thus, the government is no longer a single actor who is responsible for public problems so that privatization needs to be done as an alternative to governance reform so that this public-private partnership is considered a strategy to involve the private sector. Public and private partnerships will overcome sovereignty and find a balance of needs between partners [2].

PPP can be defined as a contract that made the Government with private service providers obtain a particular service of a specified quantity and quality at the agreed price for a certain period [3]. This definition includes several different types of contracts, which can gain different services and vary in complexity. These services include education services (management, maintenance, and support services such as transportation); service operations, such as pure management; and infrastructure (in what is often referred to as the private finance initiative) [4]. A review of empirical literature focuses on three types of services and the operation of education - vouchers, subsidies, and the management of private schools - and the private financing initiatives for the construction of the school.

PPPs must be seen within the overall context of the public-sector reform movement known as 'New Public Management (NPM) [5], which encourages :

1. Decentralization of government;

2. Separating responsibility for the purchase of public services from that of their provision;

3. Output or performance-based measurements of public services;

4. Contracting-out public services to the private sector;

\section{Privatization of public service.}

PPP is an arrangement of 'working' based on mutual commitment (implied in any contract) between the public sector and other organizations outside the public sector. 'This conceptualization highlights the importance of not only cross-sectoral involvement but of shared dedication to achieving results, from contractual relations. Mutual relationship refers to interdependence and requires individual rights and responsibilities [6]. Jointly determining goals, collaborative and consensus-based decision making. Relationships based on informal and formal beliefs are synergistic interactions among partners [2].

Partnerships are generally promoted as a means to improve the effectiveness of governance [6,7]. Partnerships are businesses that are full of value and can be promoted to maximize attractiveness for stakeholders. In general, individual actors choose to partner for one or more. The following reasons for partnership (1) To increase efficiency and effectiveness through dependence on comparative advantage, rational division of labor, and resource mobilization. This combination can cause an increase (although it may be dramatic), (2). To provide integrated multi-actor resources and solutions needed by the scope and nature of the problem being addressed. In some cases, partnerships are pursued 
compliance reasons where the law has stipulated that cross-sectoral solutions are needed (3) To move from unfavorable situations (4) To open a decision-making process to promote wider operationalization of public goods.

The PPP framework is based on policy objectives, service provision, infrastructure, capacity building, and economic development. This framework maps relatively closely related to the implementation of PPP in the real world, PPP Policy seeks to design, advocate, coordinate, or monitor public policies of various types: sectoral, national, and/or global. The partnership structure can vary from specific and informal networks of formal cross-sectoral committees, task forces, or special commissions. Strategic partnerships are mainly driven by the increasing tensions experienced by clients to remain responsive locally and to become a global integrative, and the ever-increasing need to concentrate more on the core business to develop current and future sources of competence. Because of globalization, companies have experienced increasing competitive pressure to survive and prosper in an environment where business models are created at an increasingly rapid pace $[8,9]$.

\subsection{Fashion Design Diploma}

The fashion design diploma is one of the vocational departments at the University State of Surabaya. The department's profile is to pass on fashion designers, pattern makers, fashion entrepreneurship. Education is carried out 3 years. A curriculum that emphasizes professional (ability), individual and social competencies that are contextually integrated. The core curriculum is developed and reviewed once a year. Aims to maintain the breadth, depth, coherence, and organization/organization of the courses listed in the curriculum. Study program curriculum becomes adaptive and responsive to the demands of global development.

Total credits are 120 credits. The courses are spread evenly in 6 semesters. The dissemination of courses takes into account the prerequisite courses. so that the coherence of the curriculum can be achieved. The curriculum is organized based on the level of difficulty of the course so that students can complete the level of difficulty gradually. Courses are grouped into 3 clusters, namely design, clothing, and textile courses. The distribution of balanced subject groups in each semester. $60 \%$ practice courses and $30 \%$ theory. Courses are held in the department. Fieldwork courses are carried out in the industry for 3 months. The Department cooperates with the industry where students work. Other collaborations are public lectures, fashion sources. Students hold work by carrying out fashion shows. The goal is to explore competence in the community.

\subsection{Fashion Industry}

Fashion is one of the creative industries, as expressed in the Export News Agency (March 2013) that fashion is one of 15 sub-sectors in the mapping of the creative economy in Indonesia which provides the largest contribution to Gross Domestic Product (GDP) in the creative industry category.

The fashion industry has experienced the transition of the last 20 years [10] because of the pressure of many factors:

a) The need to reduce costs,

b) Globalization: in terms of production and retail, this is a growing trend in many companies to get substantial cost benefits. Increased customer needs: the market has evolved from mass mode to segmented mode [8]. Especially in the fashion industry, customer tastes change dynamically and their expectations vary $[9,11]$. The company is expected to meet customer requirements for both product and service levels. fashion has increased its clothing market share, as customers expect greater and frequent variations in design changes [12]. Retail stores have an important role in creating a brand image and influencing customer satisfaction [13]. Finally, the level of quality service, as noted by Rayman et al. [14] is one of the main parameters for customer satisfaction.

c) Technology: has influenced the fashion industry in Indonesia in many ways and has contributed to improving customer requirements through an increase in instant knowledge of trends and new brands.

Product characteristics in the fashion industry.

a.) Short life cycle: products are often momentary, designed to capture the atmosphere of the moment; consequently, the period in which it will be sold tends to be very short and seasonal, measured in months or even weeks.

b.) Short selling season: the current fashion marketplace is very competitive and the constant need for the product range "refresh" means there are inevitable steps by many retailers to extend the "season" number, ie the frequency of all merchandise in the store is changed. In extreme cases, marked by the successful model of retailer Zara, there may be twenty seasons in the year. The implications of this tendency for the management supply chain are very clear.

c.) Long delivery time. 


\section{RESEARCH METHODOLOGY}

This research is a type of qualitative research with evaluative design, evaluating collaboration between the fashion design diploma and the fashion industry. Evaluation procedures include preparing an evaluation plan, verifying data, processing and analyzing data, and concluding. Research subjects were students and lecturers of design fashion diploma, fashion industry leaders where students practice fieldwork and designer fashion. Data collection techniques are interviews and documentation.

\section{RESULT AND DISCUSSION}

\subsection{Field Work Practice}

The practice of fieldwork is carried out in semester 6 . Practical practices refer to the Technical Internship Guidance guidelines. The procedure for implementing the practice is to prepare a practice proposal, submit a proposal is approved submit a Field Work Practice at the place using a cover letter from the Dean of the Faculty of Engineering. Practical material in the Industry is related to the fashion design industry, namely making fashion designs, pattern making, creative fabric, sewing, and managing the company. Data collected through seminars on industrial practice from 2014 to 2017 the implementation of practices in the industry, the material provided in the industry varies. The average worker in the field of sewing and creative fabric. The field of design and management has not received maximum guidance. Making a Guided design does not follow the procedure of designing a design, limited to consultation on the clothing to be made. This is because: the industry leader is not fashion design educated, the leader's time is limited in guiding. Students obtain additional competencies in the field of creative fabric, pattern maker, and sewing. However, there is one industry that guides students in the field of designing fashion designs and realizing the design. Guidance begins with a design procedure so that a design that is up to date is in line with student ideas. The results of the design are realized in the form of clothing. The assessment is carried out by the supervisor of the material that is realized, including the design and theme of the design, the suitability of the fashion embodiment with the design of the design. Based on these assessments students gain a lot of fashion design knowledge and skills. The final assessment is done in the department in the form of a seminar. The assessment component includes an assessment of industry, participation, reports, seminars. After the seminar was conducted interviews with several students as representatives of each industry, wanting material in all fields of fashion included design, pattern maker, creative fabric, sewing, and management. The form of cooperation is detailed, the purpose of fieldwork practices and the material of fieldwork practice, and the output that will be obtained after implementing the street vendors

\subsection{Teaching Practices in Industry}

There are 3 types of clothing produced in advanced fashion production practices, including party dresses. In making a party dress, a design is needed. Design refers to fashion trends. Designing party dresses for students is not easy. This is evident from the frequency of students proposing a party dress design that still needs improvement. Students must re-fix the design at least 3 times. The reason is that students still have a few ideas about design designs that are trending, as well as color trends. Likewise with the selection of materials. Material for expensive party dresses. Requires materials that match the design characteristics. There are also hi and creative and fabric. All that requires a high cost. Referring to the practice report that was presented by students, the products produced were average party dresses and modification kebaya. Party dresses are given creative decoration of fabric produced by the industry. Based on these conditions, the curriculum needs to be redesigned for effectiveness and efficiency. Referring to the standard curriculum vocational education scheme designed with a 4: 1: 1 scheme, which is 4 semesters on campus, 1 semester in industry, and 1 semester on campus or industry. The curriculum design needs cooperation with the student learning industry. The Fashion Design Diploma curriculum design carries out on-campus learning in semesters 1 to 3 . Semester 4 learning in industry, semester 5 and 6 learning on campus. Learning in the industry consists of 2 months of fieldwork practice courses, 2 months of lectures with fashion production materials, especially party dresses. Thus the cooperative model concerns the practice of fieldwork and study in the industry. For lecture material, 2 weeks are taught on campus. Practice is taught in the industry. This will save practical costs.

\subsection{Lecturer competence}

Fashion design diploma lecturer competence is in line with the fashion design field. Lecturer's educational background is master. Competent lecturer in the field of Fashion. Lecturers conduct research, attend seminars, training in fashion. But for the development of fashion that is always changing, not all lecturers can be followed. The material provided has fulfilled competencies in the industry, but the latest developments have not been reached by lecturers and students. Therefore a lecturer internship in the industry is needed. Lecturer internships are in accordance with fashion groups, namely groups of design courses, groups of pattern maker courses, fashion production courses, and textile subject groups. Each lecturer conducts a one-year apprenticeship. 


\subsection{Self-Development}

Student self-development is the development of student insight into fashion design, about real fashion design business. 2014-2017 tracer data found that the average graduate worked 2 months after graduation. The place to work in the fashion industry. Works according to their competence. This type of work is a pattern maker, an entrepreneur in the fashion sector. There are no alumni who have a profession as a designer. Interviews were conducted on 2009 alumni who were fashion designers and designers, saying that to be a designer must see the world of the fashion industry directly and observe how they work. They work with fashion designers who have lots of designs and lots of customers for 1 to 2 years. After that, pioneering business as a fashion designer. While interviews were conducted with newly graduated alumni, they were confused about how to become a designer. Based on that, a partnership between the fashion community and fashion design is needed. Interviews are carried out on several well-known designers, fashion design diplomas are allowed to follow their communities, with as members. The community activities are seminars, training, and joint fashion show events.

\section{CONCLUSIONS}

The fashion design diploma requires partnerships with the fashion industry, to improve the quality of graduates. The partnership that has been done is the practice of fieldwork that is still not maximal. The partnership model needed by the fashion design diploma is as follows.

1. Fieldwork practice with more complete material, namely design, pattern maker, sewing, creative fabric, and management.

2. Lecturer internship within one month, according to the competency qualifications of each, namely design, pattern maker, fashion production, creative fabric, with a mutually agreed time.

3. Studying in the fashion industry for one semester, with dress material with fashion techniques

4. The involvement of students is on the verge of graduating with the design fashion community

\section{REFERENCES}

[1] World Bank, Asian Development Bank, and InterAmerican Development Bank. (2014). PublicPrivate Partnership Reference Guide Version 2.0. Washington: The World Bank Publications.

[2] Derick W. Brinkerhoff1 And Jennifer M. Brinkerhoff2 1RTI International (Research Triangle Institute), USA. George Washington
University, USA public administration, and development public Admin. Dev. 31, 2-14 (2011) Published online in Wiley Online Library(wileyonlinelibrary.com)DOI:10.1002/pad. 584.

[3] Taylor, R. J. 2003. "Contracting for Health Services."InPrivate Participation in Health ServicesHandbook, eds. A. Harding and A. Preker,195-204. Washington, DC: World Bank.

[4] LaRocque, N. and H. Patrinos. 2006. "Choice and Contracting Mechanisms in the education sector." World Bank, Washington, DC.

[5] Yescombe, E.R. (2007). Public-Private Partnership, Principles of Policy and Finance. London: Elsevier Ltd.

[6] Bovaird T. 2004. Public-private partnerships: from contested concepts to prevalent practice. International Review of Administrative Sciences70(2): 199-215.

[7] Osborne SP (ed). 2000. Public-Private Partnerships: Theory and Practice in International Perspective. Routledge: London.

[8] D'Aveni, R.A., 2002. Competitive pressure systems. MIT Sloan Management Review 44 (1), 39-49.

[9] Dess, G.G., Rasheed, M.A., McLaughlin, K.J., Priem, R.L., 1995. The new corporate architecture. Academy of Management Executive 9 (3), 7-18.

[10] Rhodes RAW. 1997. Understanding Governance: Policy Networks, Governance, Reflexivity, and Accountability. Open University Press: Buckingham, UK.

[11] Barney, J.B., 1995. Looking inside for competitive advantage. Academy of Management Executive 9 (4), 49-61.

[12] Brown, D., Wilson, S., 2005. The Black Book of Outsourcing: How to Manage the Changes, Challenges, and opportunities. John Wiley, New York.

[13] Quinn, J.B., 1999. Strategic outsourcing: leveraging knowledge capabilities. Sloan Management Review 40, 9-21.

[14] Public-Private Partnerships: Perspectives On Purposes Publicness, And Good Governance.

[15] Cross, N. 2004. "Expertise In Design: An Overview.” Design Studies25: 427-441.

[16] Koppenjan J. 2005. The formation of public-private partnerships: lessons from nine transport 
infrastructure projects in the Netherlands. public administration 83(1): 135-157.

[17] The Role and Impact of Public-PrivatPartnerships in Education. Harry Anthony Patrinos. Felipe Barrera-Osorio. Juliana Guáqueta. 2009 The International Bank for Reconstruction and Development / The World Bank.

[18] Demand Forecasting in the Fashion Industry: A Review. Regular Paper. Maria Elena Nenni1,*, Luca Giustiniano2 and Luca Pirolo2*. International Journal of Engineering Business Management. Special Issue on Innovations in Fashion Industry.

[19] Frings G.S., (2005). Fashion: From Concept to Consumer, Pearson Education.

[20] Sekozawa T., Mitsuashi H., Ozawa Y., (2011). Oneto-One recommendation system in apparel online shopping. Electronics and Communications in Japan,94 (1), pp. 51-60.

[21] Marufuzzaman M., Ahsan K.B., Xing K., (2009).Supplier selection and evaluation method using analytical Hierarchy Process (AHP): a case study on an apparel manufacturing organization. Int. J. ValueChain Management, 3 (2), pp.224-240.

[22] Battistoni E., Fronzetti Colladon A., Mercorelli G.(2013). Prominent determinants of consumer basedbrand equity. International Journal of EngineeringBusiness Management.

[23] Chan F.T.S., Chan H.K., (2010). An AHP model for the selection of suppliers in the fastchanging fashion market. International Journal of AdvancedManufacturing Technology, 51, pp.1195-1207.

[24] Shubhapriya B., Byoungho J., (2012). A conceptual process of implementing quality apparel retail store attributes An application of Kano's model and the quality function deployment approach. InternationalJournal of Business, Humanities, and Technology, 2(1), pp.174-183.

[25] Rayman D., Burns D.J., Nelson C.N., (2011). Apparel product quality: its nature and measurement. Journal of Global Academy of Marketing Science, 21 (1), pp.66-75.

[26] D’Amico S., Giustiniano L., Nenni M.E., Pirolo L.,(2013). Product Lifecycle Management as a tool to create value in the fashion system. InternationalJournal of Engineering Business Management.
[27] De Felice F., Petrillo A., Autorino C., (2013). Keysuccess factors for organizational innovation in thefashion industry. International Journal ofEngineering Business Management 